\title{
Jatkuvan koulutuksen pohjoismaista oppia
}

\begin{abstract}
Haavio, Matti 1987. Jatkuvan koulutuksen pohjoismaista oppia. Aikuiskasvatus 7, 1-2, 4-9. - Artikkelissa tarkastellaan eri Pohjoismaiden aikuiskasvatuksen kehittämisen painopisteitä ja suuntia. Aikuiskasvatuksen kehittämisessä ovat Pohjoismaat toimineet eri tavoin: Ruotsissa on korostettu tasa-arvoa, Tanskassa hajautusta, Norjassa lainsäädäntöä ja Suomessa koulutusjärjestelmän kokonaisuutta. Artikkelissa kiinnitetään erityistä huomiota suomalaisen aikuiskasvatuspolitiikan sisällön kehittelyyn.
\end{abstract}

Aika näyttää olevan kypsä siihen, että suomalaista koulutusjärjestelmää tarkastellaan kokonaisuutena. Opetusministeriössä on ryhdytty valmistelemaan eduskunnalle mahdollisesti annettavaa hallituksen koulutuspoliittista selontekoa. Valmistelutyöryhmä on saanut evästyksen, jonka mukaan ohjenuorana on pidettävä jatkuvan koulutuksen toteuttamista.

Kun näin on, on hyvä tietää mistä voisi olla kysymys. Tarkastelen seuraavassa pohjoismaista tilannetta ja koetan selvittää, olisiko tätä kautta tarjolla lisäoppia. Aineisto on kertynyt varsinkin Oslossa 11._-12.2.1987 järjestetyn seminaarin yhteydessä - etukäteen, paikan päällä ja jälkikäteen.

Kaikissa Pohjoismaissa jatkuvan koulutuksen ajatukset ovat kietoutuneet aikuiskoulutukseen. Käytettävissä olevien selvitysten mukaan Pohjoismaiden "neljä suurta" asettuvat aikuiskoulutukseen panostajina riviin siten, että julkisen rahoituksen osalta ensimmäisenä olisi Ruotsi, toisena Suomi, kolmantena Tanska ja neljäntenä Norja; jos huomioon otettaisiin kaikki koulutus ja sen julkinen rahoitus, järjestys vaihtuisi ensimmäistä sijaa lukuun ottamatta kokonaan, ja viimeisenä olisi Suomi. Rahoitusluvut heijastelevat tietysti muun muassa aiempien vuosien ajatuksia, suunnitelmia ja päätöksiä, mutta tässä keskityn siihen, mitä eri maiden keskustelussa nykyisin korostetaan. Näinkin meneteltäessä myös menneisyys on toki läsnä.

\section{Ruotsi}

Ruotsin aikuiskoulutuksen kehitystä leimasi viime vuosikymmenellä ripeä kasvu. Määrärahat lisääntyivät jyrkästi. Aikuiskoulutus oli osa yhteiskunnan tasa-arvopolitiikkaa. Vuosia 1970-76 on kuvattu radikaalin tasa-arvon jaksoksi. Poliittisten voimasuhteiden vaihduttua tasa-arvotavoitteita ei hylätty, mutta toiminta ja sen sävy muuntuivat tavalla, joka on antanut aiheen luonnehtia vuosia 1976-82 koulutuksellisen tasa-arvon kaudeksi. 80-luvulla määrärahojen kasvu on pysähtynyt miltei tyystin. On ryhdytty arvioimaan toteutunutta (esim. Olofsson \& Rubenson 1986), mutta myös etsimään tuoreita ponnistuspisteitä ja valmistautumaan 90-lukuun. Tällä hetkellä keskustellaan niin "uudesta koulutuskuilusta" (Abrahamsson \& Rubenson 1986) kuin "ammattilaistumisansasta" (Broady 1986): koulutukseen liittyvä eriarvoisuus elää ja muuntuu, ja ammatillisesti erikoistuva ja erikoistava koulutus voi johtaa hyvän lisäksi hankaluuksiin.

80-luvun saavutuksina jäänevät historiaan suhteellisen laaja-alainen aikuiskoulutuslaki (Lag 1984) sekä kehittämisrahastot (ks. Edström 1986, 199). Laki koskee kuntien ja landstingien järjestämää koulutusta, rahastot yrityksiä ja niiden mahdollisuuksia kouluttaa, rahastoida voittojaan koulutustarkoituksiin ja välttää veroja. 
Esimerkiksi jatkuvasta koulutuksesta Ruotsissa ei juuri puhuta. Toisaalta katsotaan, että koulutusjärjestelmä on jo nykyisin sillä tavoin kattava, että elinikäisen oppimisen ideat toteutuvat pitkälti käytännössä. Muun muassa opintososiaalisten etujen kehittyneisyyden vuoksi monet ovat valmiit sanomaan ruotsalaisen koulutuspolitiikan olevan aikuiskoulutusta koskevilta osiltaan jaksoittaiskoulutuksen politiikka, siis sitä mitä etenkin OECD on viime vuosikymmeninä suosittanut puhuessaan työn ja koulutuksen vuorottelusta (OECD:n terminä on recurrent education, ruotsiksi återkommande utbildning; jaksoittaiskoulutuksesta ja Ruotsin koulutuspolitiikasta ks. Abrahamsson 1986, 58-65).

\section{Tanska}

Tanskan aikuiskoulutuksen ja -kasvatuksen (ks. Danmark 1982) tällä hetkellä keskeinen tavoitteisto sisältyy kymmenen kohdan ohjelmana tunnettuun kansankäräjien hyväksymään asiakirjaan (Folketinget 1984; liite). Teemana ovat hallinnon hajautus ja yksikköjen ja yksilön itsenäisyys. Toteuttamisen tieksi on valittu kokeilu- ja kehittämistoiminta, joka julkisen vallan rahoittamina projekteina on levinnyt kaikkialle maahan (Balle-Petersen \& al. 1986, Udviklingscenter 1986-87).

Ohjelmaa ei kansankäräjillä suinkaan hyväksytty yksimielisesti; sitä voidaan pitää poliittisen keskustan (lähinnä radikale venstren) työn tuloksena. Liikkeelle oli lähdetty vuonna 1983 tehdyllä aloitteella, mutta vasta vuonna 1984 tehty, tarkistettu aloite kantoi hedelmää. Ohjelma on tanskalaisen perinteen mukainen ainakin sikäli, että lapsuusiän koulutuksesta tehtiin vuonna 1969 yhdeksän kohdan kansankäräjäpäätös ja nuorisoasteen koulutuksesta vastaavanlainen ohjelmapäätös vuonna 1980.

\section{Norja}

Alussa mainitsemani Oslon kokouksen aiheena oli Norjassa laaditun elinikäistä oppimista koskevan raportin (Utredning 1986) pohjoismainen arviointi. Järjestäjänä oli Pohjoismaiden ministerineuvosto. Arvioitsijoita oli paikalla viitisenkymmentä, Skandinaviasta, Suomesta ja Islannistakin (jonka tilanteen jätän tässä käsittelyttä).

Raporttia - itse asiassa hallituksen asettaman komitean mietintöä - valmisteltiin viisi vuotta. Elinikäisen oppimisen piiriin kuuluisi komitean mukaan kaikki koko elämän aikana ja eri elämäntilanteissa tapahtuva oppiminen.
Mietinnössä painottuu kuitenkin aikuiskasvatus. Etusijalla on aikuisten osallistuminen koulutukseen ja samalla se, miten tätä voitaisiin edistää. Ehdotuksista ehkä konkreettisimmat koskevat työssä olevien opintovapaata ja aikuisten taloudellista opintotukea. Opintovapaasta luonnostellaan lakia, opintotukikysymyksissä keskitytään järjestelmän luonnetta ja piirteitä koskeviin seikkoihin. Mukana olisi myös kestoltaan sangen lyhyitä koulutusjaksoja koskevan julkisen tuen ohjelma.

Komitea korostaa erityisesti työn ja koulutuksen vuorotteluun perustuvan järjestelmän luomista ja tulee näin tukeneeksi OECD:n jaksoittaiskoulutusta koskevia suosituksia. OECD mainitaan eksplisiitistikin taustavaikuttajana.

Ehdotuksia ei toki ole tehty pelkän tyhjiön täyttämiseen - Norjassa on eri tavoin keskusteltu elinikäisestä oppimisesta runsaat kaksikymmentä vuotta, ja tästä on merkkejä myös virallisissa dokumenteissa. Aikuiskasvatusta koskeva melko laaja-alainen laki säädettiin jo runsaat kymmenen vuotta sitten (Lov 1976; kokemuksista ks. Vettenranta 1984). Voidaankin sanoa, että vuoden 1986 raportti sekä kokoaa entistä että luo uutta.

Aikuiskasvatuksen kentän ulkopuolelle ja samalla elinikäisen oppimisen tai jatkuvan koulutuksen kannalta hyvin kiintoisille alueille johdattaa ehdotus, jonka mukaan Norjaan tulisi säätää koulutuksen "peruslaki". Se sisältäisi koulutuspolitiikan päälinjat, lähtökohdat ja tavoitteet. Se ei rakentuisi nykyisen aikuiskasvatuslain varaan, mutta sen säätäminen aiheuttaisi muutoksia tähän lakiin kuten mahdollisesti muihinkin. Kukin erityissäädös - ja Norjassa on raportin mukaan voimassa nelisenkymmentä koulutusalan lakia ja muuta Norges Lover -kokoelmaan otettua koulutussäädöstä - saisi täyden merkityksensä vasta luettuna yhdessä peruslain kanssa.

Koulutusjärjestelmän kokonaisuuteen liittyy myös ajatus, jonka mukaan tutkintojen järjestelmää tulisi kehittää siten, että nykyisen koulutuksen muodolliset tutkinnot eivät olisi ainoita merkityksellisiä todisteita koulutuksesta. Opintosuoritukset olisi voitava dokumentoida ja lukea hyväksi entistä monipuolisemmin. Tämäntapaisia ehdotuksia on tehty parin vuoden takaisessa mietinnössä (Utredning 1985), ja vuoden 1986 raportissa niihin viitataan kannattaen.

Norjan opetusministeriö on pyytänyt elinikäistä oppimista koskevasta raportista runsaasti lausuntoja, ja ne saataneen kevään 1987 aikana. Oslon pohjoismainen kokous antoi norjalaisille tuntuman siitä, että kehittämistyössä ollaan oikeilla jäljillä: vastaanotto oli varsin myönteinen. Tuntumaa ja varmuuttakin tarvitaan, sillä tarkoituksena on valmistella suurkäräjiä varten elinikäistä oppimista koske- 
va hallituksen selonteko ja ryhtyä myös käytännön toteuttamistoimiin. Kurottumista aikuiskasvatuksen ulkopuolelle saattaa haitata esimerkiksi se, että Norjassa ei enää muutamaan vuoteen ole ollut opetusministeriön yhteistä suunnitteluyksikköä; aikuiskasvatusosasto sen sijaan on suurehko ja jakautunut useihin toimistoihin.

\section{Suomi}

Suomi on joka tapauksessa tässä käsiteltävistä maista se, jossa elinikäinen oppiminen on haluttu määrätietoisimmin tulkita koko koulutusjärjestelmän kysymykseksi. Meilläkin on tosin lähdetty liikkeelle aikuiskoulutuksesta. Tärkeänä kiintopisteenä on valtioneuvoston vuonna 1978 aikuiskoulutuksen suunnittelu- ja kehittämisperiaatteista tekemä päätös, jonka mukaan Suomen koulutusjärjestelmää kehitettäessä sovelletaan jatkuvan koulutuksen periaatetta.

Periaatteen ulottuvuuksien selvittämiseksi ja konkretisoimiseksi opetusministeriö asetti aluksi toimikunnan ja sittemmin projektiryhmän. Mietinnöissään nämä elimet ehdottivat toimia, joiden avulla voitaisiin poistaa koulutuksen turhat kertautumiset ja umpikujat ja saattaa koulutusjärjestelmä koskemaan ja tukemaan kaikkea oppimista (Toimikunta 1983, Projektiryhmä 1986). Sivistyspoliittinen ministerityöryhmä käsitteli syksyllä 1986 mietintöihin ja niistä saatuihin lausuntoihin perustuvan aineiston valossa mahdollisuuksia tehdä jatkuvan koulutuksen toteuttamista koskeva valtioneuvoston päätös. Ministerityöryhmä arvioi parhaaksi vaihtoehdoksi, että opetusministeriö ryhtyisi valmistelemaan hallituksen koulutuspoliittista selontekoa, jonka keskeisenä lähtökohtana olisi jatkuvan koulutuksen periaatteen toteuttaminen. Valmistelutyörymä asetettiin 22.12.1986, ja jatkuvan koulutuksen rinnalla toimeksiannossa korostettiin kokonaisotetta: "Keskeisenä pidetään jatkuvan koulutuksen toteuttamista ja samałla koulutusjärjestelmän osien entistä parempaa niveltämistä."

\section{Osviittoja}

Mitä voisimme oppia pohjoismaisista hankkeista ja ajatuksista? Mitä niissä olisi sellaista, jota voitaisiin ottaa varteen suomalaista koulutusta ja koulutuspolitiikkaa kehitettäessä? Ja - kun näyttää siltä että elinikäisestä oppimisesta ja jatkuvasta koulutuksesta puhuttaessa puhutaan suurelta osin aikuiskoulutuksesta millaisia osviittoja voisi olla saatavissa aikuiskoulutuspolitiikan tarpeisiin?
Tärkeimpiä tekijöitä voitaisiin koota seuraavanlaiseksi asetelmaksi:

$\begin{array}{ll}\text { Ruotsista } & \text { tasa-arvon korostaminen } \\ & \text { kehittämisrahastot } \\ \text { Tanskasta } & \text { hajautus } \\ \text { Norjasta } & \text { aikuisten osallistuminen } \\ & \text { aikuisten aikuisuus } \\ & \text { opintotuki } \\ & \text { onko nykyisin jo varaa jaksoit- } \\ & \text { taiskoulutukseen? } \\ & \text { "peruslaki" } \\ \text { Omasta takaa } & \text { koulutusjärjestelmän kokonai- } \\ & \text { suus }\end{array}$

\section{Tasa-arvo}

Tasa-arvokysymysten korostaminen on Suomessakin aiheellista, koska koulutukseen valiutumisen tärkein suuntaava tekijä näyttää yhä vielä olevan sosiaalinen tausta. Sukupuolten välinen koulutustasa-arvo on meillä suhteellisen pitkällä, mutta esimerkiksi keskiasteen ammatillinen koulutus on erittäin suuressa määrin osittunut sukupuolen mukaan (vaikka tämän koulutuksen kokonaisuus on jakautunut sukupuolten kesken miltei täsmälleen tasan), ja vapaan sivistystyön opintoja harrastavat ennen kaikkea naiset. Henkilöstökoulutuksen mahdollisuudet ovat toistaiseksi painottuneet siten, että hierarkiassa ylimpiin kerroksiin kuuluvat ovat voineet osallistua koulutukseen aivan toisessa määrin kuin alimpiin kuuluvat. Luetteloa voisi jatkaa. Usein on huomautettu, että tämäntapaisten tilanteiden korjaaminen ei käytännössä onnistu. Mutta kun vaikkapa ruotsalaisissa seurantatutkimuksissa on todettu että eriarvoisuuksia ei ole saatu poistetuksi tai ne ovat muuntuneet uudenlaisiksi, ei ole tarkoitettu että ponnisteluista olisi luovuttava. Tämä tulisi ottaa toiminnan linjaksi Suomessakin.

Erityisesti aikuiskoulutukseen näitä seikkoja voitaneen lähteä sisällyttämään muun muassa valtioneuvoston 5.3.1987 tekemän, potentiaaliselta merkitykseltään viime vuosikymmenten huomattavimpiin kuuluvan aikuiskoulutuspäätöksen (Valtioneuvosto 1987 a) pohjalta. Päätöksessä määritetään periaatteet, joita noudatetaan suunniteltaessa ammatillisen aikuiskoulutuksen rahoitusjärjestelmän uudistamista, ja se koskee sekä koulutuksen järjestämistä että toimeentuloturvaa. Julkisen sektorin lisäksi selkeää rahoitusvastuuta osoitetaan yksityiselle sektorille. Yksityisen sektorin rooli ja rahoitusvastuu korostuu erityisesti henkilöstökoulutuksessa. Julkisen sektorin ylläpitämät oppilaitokset ja korkeakoulut tulevat edelleen aktiivisesti osallistumaan henkilöstökoulutuksen järjestämiseen, mutta vastuu tämän koulutuksen rahoittamisesta osoitetaan työnantajalle. 


\section{Rahastointi}

Rahoituspäätöksen ei varmaan ole tarkoitettu olevan ristiriidassa asetelman muidenkaan tekijöiden kanssa. Koulutusrahastokysymyksistä ei Suomessa toistaiseksi ole virallista kantaa. Päätökseen liittyvässä perustelumuistiossa viitataan kuitenkin myönteisessä sävyssä tarpeeseen luoda koulutusrahastojärjestelmä. Asiaa on selvitelty sekä työmarkkinajärjestöissä että muun muassa komiteatyönä, ja jatkuvaa selvittelyä luvataan myös uuden hallituksen ohjelmassa: "Koulutuksen kehittämiseksi selvitetään yritysten sisäisten ja välisten rahoitusjärjestelmien toteuttamista" (Hallitus 1987). Nyt olisi aika käydä tosimielinen keskustelu siitä, millainen ratkaisu sopisi Suomeen.

\section{Hajautus}

Entä hajautus, Tanskan aate? Yleisimmän tason virallinen linja on Suomessakin selvä: "hallinnon rakennetta ja toimintaa kehitetään hallinnonaloittain siten, että hallinnollinen ratkaisuvalta annetaan asteellisesti alimmalle viranomaiselle, jolla on riittävät edellytykset toimivallan käyttämiseen asianmukaisella tavalla", todetaan valtioneuvoston 29.1.1987 tekemässä hallinnon hajauttamista koskevassa päätöksessä (Valtioneuvosto 1987 b). Taustat ja ajatusperinteet ovat tällä alalla laajat ja pitkät, mutta tulokset eivät ole kiistattomia. On selvää ja todettu monesti, että esimerkiksi nykyisten koulutusalan keskusvirastojen lakkauttaminen tai vähemmänkin mullistava uudistaminen on ongelmallinen asia. Vaikeudet ovat myös periaatteellisia. Hyvinvointivaltioideologiaan kuuluva alueellisen tasa-arvon tavoite ei välttämättä, virallisista puheista riippumatta, yhdisty aivan luontevasti hajautusajatuksiin. Jos yleinen sääntelyjärjestelmä puuttuu taı puretaan, saattaa syntyä palveluihin liittyvää alueellista eriarvoisuutta tai ainakin epätasaisuutta. Näihin ongelmiin on kiinnitetty huomiota muun muassa hyvinvointivaltion norjalaista mallia tutkittaessa (Kuhnle 1980).

\section{Aikuisuus}

Asetelman norjalaisopeista liittyvät kiinteimmin toisiinsa aikuisten osallistuminen ja aikuisuus sekä opintotuki. Näiden ulottuvuuksien pohdinta on tuttua Suomessakin, mutta edelleenkehittely on varmasti tarpeen. Eräissä meikäläisissä aikuiskoulutuskokeiluissa on sangen selvästi voitu havaita, että jos aikuisia opetetaan ja kohdellaan kuin vajavaltaisia, tulokset jäävät huonoiksi. Aikuiset ovat itsenäisiä ja itsenäisinä kohdeltavia ihmisiä. Koska heidän on voitava myös elää, ei riitä että tarjolla on koulutusjärjestelmä organisaatioineen: on voitava myös osallistua koulutukseen vailla kohtuuttomia uhrauksia. Siksi opintotuki- ja opintososiaalisten seikkojen hoitaminen on äärimmäisen tärkeätä ja tulisi ulottaa selkeästi muuallekin kuin työllisyyskoulutuksen piiriin. Jonkinlaisena hyvän tien alkuna voidaan pitää opintotukilain muutosta, joka tulee voimaan heinäkuun alussa 1987 (Laki 1987). Esimerkiksi lyhytkestoisen koulutuksen pulmia muutos ei poista. Olisiko toivo siis pantava valtioneuvoston maaliskuiseen päätökseen? Entä hallitusohjelmaan? Se lupaa, että aikuisten opintotuen kehittämistä selvitetään (Hallitus 1987).

\section{Jaksoittaiskoulutus}

OECD:n suositteleman jaksoittaiskoulutuksen ajatuksia ei Suomessa haluttu 1970-luvulla ryhtyä ajamaan ainakaan keskeisenä koulutusstrategiana, koska tärkeimpänä pidettiin lapsuus- ja nuoruusiän koulutusta koskevien uudistusten toteuttamista. Nykyisin nämä uudistukset ovat varhaiskasvatukseen liittyviä ehkä lukuun ottamatta toteutuneet varsin pitkälle, ja saattaisi olla aika tarkistaa näkemyksiä. Peruskoulutus on taattava kaikille eikä sitä pidä siirtää aikuisikään, mutta aukot on paikattava ja jatkuvan koulutuksen tarpeet tunnustettava sikälikin, että työn ja koulutuksen vuorottelu muuttuu todellisuudeksi. Jos vertailutilastot pitävät suunnilleenkaan paikkansa, Suomi on neljästä tässä käsitellystä Pohjoismaasta ainoa, jonka julkiset koulutusmenot ovat 1980-luvun alkuvuosina olleet bruttokansantuoteosuuksin mitattuina pienemmät kuin 70-luvun alkuvuosina (vaikka absoluuttinen panostus on tietenkin lisääntynyt huomattavasti). Varaa on, jos tahtoa riittää.

\section{Peruslaki}

"Peruslaki" on ajatuksena haastava kysymys. Meillä on jo pitkähkö kokemus koulutusalan kehys- tai puitelaeista, niin korkeakoululaitosta kuin keskiasteen koulutustakin koskevista. Miksi ei astuttaisi selkeää askelta eteenpäin ja valmisteltaisi lainsäädäntöä, jonka alana olisi koko koulutus ja koulutuspolitiikka? Vai onko puheiden koulutuksen ratkaisevasta merkityksestä yksilölle ja kansakunnalle jäätävä vain puheiksi?

\section{Koulutusjärjestelmän kokonaisuus}

Lähtökohtia voisi tarjota se, että olemme tavallaan jo pitemmällä kuin asian esiin nostanut Norja: suomalainen jatkuvan koulutuksen suunnitteluhan on nimenomaan koko koulutusjärjestelmää koskevaa suunnittelua. Tätä painotusta olisi kehiteltävä ja hyödynnettävä.

Millaista koulutuspolitiikan siis tulisi olla? Sen tulisi olla hyvin perusteltua koulutustarpeen ja -tarjonnan politiikkaa. Mutta sen tulisi olla myös osallistumisen politiikkaa. Edellytykset olisi taattava sekä taloudellisesti että säännöksiä riittävästi uusimalla. 


\section{Kirjallisuus}

\section{Ruotsi}

Abrahamsson K. 1986. Adult Participation in Swedish Higher Education. A Study of Organizational Structure, Educational Design and Current Policies. Stockholm: Almqvist \& Wiksell.

Abrahamsson K. \& Rubenson K. (red.) 1986. Den "nya" utbildningsklyftan - 90-talets utmaning. En bok om vuxenutbildningsreformer, kunskaper och jämlikhet. Stockholm: Liber.

Broady D. (red.) 1986: Professionaliseringsfällan Vuxenutbildning. Arbetsdelning. Yrkeskunnande. En bok från Forum för vuxenutbildningsdebatt. Stockholm: Carlssons.

Edström Ö. 1986. Henkilöstökoulutus - Ruotsin aikuiskasvatuksen uusi painopistealue. Aikuiskasvatus 6, 4, 198-199.

Lag 1984. Vuxenutbildningslag. Svensk författningssamling 1984: 1118. Stockholm: Liber.

Olofsson L.-E. \& Rubenson K. 1986. 1970-talets vuxenutbildningsreformer. Reflexioner kring strategier och utfall. Stockholm: Högskolan för lärarutbildning i Stockholm. Institutionen för pedagogik. Rapport $9 / 85$.

\section{Tanska}

Balle-Petersen M., Hansen B. K., Jacobsen K. M. \& Wahlgren B. 1986. At overskride grænser. Første melding om den landsdækkende erfaringsindsamling fra folkeoplysningens udviklingsarbejde under 10 punkts programmet. København: Udviklingscenter for folkeoplysning og voksenundervisning.

Danmark 1982. Jakso Danmark teoksessa Engelhardt J. (red.): Voksenundervisningen i Norden, 55-103. København: Nordisk Ministerråd.

Folketinget 1984. Folketingsbeslutning om et 10 punkts program for voksenundervisning og folkeoplysning. Folketingstidende 1983-84 (2. samling). Tillæg C. København 1985: J. H. Schultz.

Udviklingscenter 1986-87. Nyhedsbrev fra Udviklingscenter for folkeoplysning og voksenundervisning. Nr. 1 (marts 1986) - nr. 5 (marts 1987).

\section{Norja}

Kuhnle S. 1980. National Equality and Local Decision-making: Values in Conflict in the Development of the Norwegian Welfare State. Acta Sociologica 23, 2-3, 97-111.

Lov 1976. Lov om voksenopplæring. Norsk Lovtidend 1976: 35. Oslo: Statsministerns kontor.

Utredning 1985. Dokumentasjon av kunnskaper og ferdigheter. En utredning om voksnes rett till dokumentasjon i samsvar med lov om voksenopplæring $\S 3$. Norges offentlige utredninger 1985: 26. Oslo - Bergen - Stavanger - Troms $\varnothing$ : Universitetsforlaget.

Utredning 1986. Livslang læring. Norges offentlige utredninger 1986: 23. Oslo - Bergen - Stavanger - Tromsø: Universitetsforlaget. - Mietintöä koskevia, Pohjoismaiden ministerineuvoston Oslossa 11.-12.2.1987 järjestämää arviointiseminaaria varten laadittuja raportteja: Abrahamsson K. Livslang læring (NOU 1986: 23) - en kommen- tar från svensk horisont. Haavio M.: Elinikäinen oppiminen norjalaiseen tapaan. Ret till uddannelse - også for voksne? (tanskalainen raportti, tekijää ei ilmoitettu).

Vettenranta S. 1984. Laki ei takaa tasa-arvoa Norjan aikuiskasvatuslain vaikutuksia. Aikuiskasvatus 1984, 4, 2, 90—93.

\section{Suomi}

Hallitus 1987. Pääministeri Harri Holkerin hallituksen ohjelma. Helsinki: Valtion painatuskeskus.

Laki 1987. Laki opintotukilain muuttamisesta. Suomen säädöskokoelma 1987: 95. Helsinki: Valtion painatuskeskus.

Projektiryhmä 1986. Jatkuvan koulutuksen projektiryhmän muistio. Opetusministeriön työryhmien muistoita 1986: 1. Helsinki: Valtion painatuskeskus.

Toimikunta 1983. Jatkuvan koulutuksen toimikunnan mietintö. Komiteanmietintö 1983: 62 . Helsinki: Valtion painatuskeskus.

Valtioneuvosto 1987 a. Valtioneuvoston periaatepäätös ammatillisen aikuiskoulutuksen rahoittamisen suunnitteluperiaatteista. Valtioneuvoston yleinen istunto 5.3.1987, pöytäkirjan liite.

Valtioneuvosto 1987 b. Valtioneuvoston päätös hallinnon hajauttamisesta. Valtiovarainministeriön kirjeessä valtioneuvoston kanslialle ja ministeriöille 29.1.1987 n:o J 72/22/87.

\section{Liite}

TANSKAN KANSANKÄRÄJIEN PÄÄTÖS AIKUISOPETUSTA JA KANSANSIVISTYSTÄ KOSKEVASTA 10 KOHDAN OHJELMASTA Hyväksytty toukokuun 30. päivänä 1984

Kansankäräjät kehottaa hallitusta ryhtymään toimiin, joiden avulla voidaan kehittää aikuisopetuksen ja kansansivistystyön edellytyksiä sekä lisätä aikuisten mahdollisuuksia osallistua näihin toimintoihin.

\section{Lähtökohtina pidetään seuraavia periaatteita:}

1. Aikuisopetusta ja kansansivistystyötä kehitetään hajautetun mallin mukaan siten, että osallistujilla, opettajilla ja toiminnan järjestelyistä huolehtivilla on pitkälle ulottuva vapaus päättää sisällöstä ja muodoista.

Julkinen valta takaa aikuisväestölle laajan opetustarjonnan, jossa mukana ovat sekä kansansivistystyö että yleissivistävä ja ammatillinen aikuisopetus, ja tukee taloudellisesti aikuisten osallistumista näihin toimintoihin.

2. Kansansivistystyötä ja kansanopistoa koskevat kehittämisen painopisteet valitaan noudattaen suurinta mahdollista itsenäisyyttä suhteessa julkiseen valtaan.

3. Erilliskursseina annettavaa yleissivistävää opetusta (yhdeksättä ja kymmenettä luokkaa vastaava opetus sekä ylioppilastutkintoa korvaavaan, erityisesti aikuisille suunniteltuun tutkintoon johtava kaksivuotinen koulutus) kehitetään varsinaiseksi aikuisopetukseksi, joka ei ole sidoksissa kansakoulun eikä lukion opetussuunnitelmiin, kokeisiin ja tutkintoihin. 
4. Julkisen vallan vaikutuspiirissä olevaa ammatil-
lista aikuisopetusta lisätään, lavennetaan ja muokataan joustavammaksi.

5. Julkista tukea jaettaessa asetetaan etusijalle opetus- ja kansansivistystoiminta, joka on tarkoitettu yhteiskunnan laajasta koulutustarjonnasta heikosti osallisiksi päässeille aikuisille.

6. Osallistumisen taloudellisia ja työhön liittyviä edellytyksiä parannetaan mm. perustamalla koulutusrahasto. Aikuisopintotukea jaettaessa pidetään lähtökohtana, että yksilö voi vapaasti valita osallistumisensa kansansivistystyön moniin toimintamuotoihin, näihin luettuna kansanopisto, yleissivistävään aikuisopetukseen ja ammatilliseen aikuisopetukseen. Tukea jaettaessa kiinnitetään erityistä huomiota kohdassa 5 mainittuihin ryhmiin.
7. Mahdollisuus koulutusvapaisiin, joka jo nykyisin on eräiden ryhmien käytettävissä, laajennetaan asteittain koskemaan kaikkia työntekijöitä sekä itsenäisiä ammatinharjoittajia, varsinkin pienyrittäjiä.

8. Kokeilu- ja kehitystyötä tehostetaan pitäen silmällä nykyisten järjestelyjen uudistamista sekä täysin uusien muotojen kehittämistä.

9. On taattava, että aikuisopetuksen ja kansansivistyksen opettajilla on erityisalatietämyksen lisäksi kokemusta niistä työtehtävistä ja siitä arkipäivästä, josta osanottajat tulevat, ja että nimityksissä painotetaan pikemmin tosiasiallisia ammatillisia ja pedagogisia edellytyksiä kuin muodollista pätevyyttä.

10. Aikuisilla tulee olla oikeus todellisten tietojensa ja taitojensa dokumentointiin ja hyväksi lukemiseen riippumatta siitä, miten ne on hankittu. 


\section{AIKUISKASVATUS}

\section{The Finnish Journal of Adult Education \\ Vol. 7, 1-2/1987 \\ ISSN 0358-6197 \\ Summary}

Haavio, Matti 1987. Nordic trends in continuing education.

- The article looks into developments in adult education in the Nordic countries. The emphasis in Sweden has been on equality, in Denmark it has been on decentralization, in Norway on legislation and in Finland on the education system as a whole. Particular stress is laid on life-long learning, continuing education and developing the content of adult education policy in Finland. 